\title{
A Contribution to a Politico-Liberal MODEL OF JUDGMENT
}

\author{
- Urszula Lisowska -
}

\begin{abstract}
The paper intends to initiate a discussion on the politico-liberal concept of judgment. It is argued that whilst political liberalism (PL) - presented as an account of political objectivity - already appeals to judgment, this conception is an unsatisfactory one. This critical assessment is supported by the juxtaposition of PL with an Arendtian understanding of political objectivity which offers a more robust account of judgment. In the conclusion, the possibility of applying the Arendtian solution to PL is outlined. Keywords: political liberalism; political objectivity; judgment; John Rawls; Martha Nussbaum; Hannah Arendt; Linda M.G. Zerilli.
\end{abstract}

Published online: 15 November 2019

The purpose of this paper is to make the first contribution to supplementing political liberalism (PL) with an account of political judgment. The concept of PL is employed in the sense that was defined independently by John Rawls ${ }^{1}$ and Charles Larmore ${ }^{2}$ in the 1980s and 1990s, and is recently being developed by - among others - Martha C. Nussbaum. It is argued that PL is essentially a theory of political objectivity and, as such, should crucially involve a conception of political judgment or judgment. ${ }^{3}$ The latter refers to the faculty of formulating political opinions as well as to its products, i.e. the opinions themselves (that is: it is argued that a robust account of judgment should cover both of these aspects).

Although the paper is largely critical, this criticism is intended to pave the way for a revision of PL. Namely, it is argued that while in its current form PL recognises the importance of judgment, its understanding of the concept is still underdeveloped. Yet, its fuller appreciation seems crucial to ensuring the feasibility of PL. This assessment is first formulated based on the analysis of PL itself and later supported by the insights derived from the Arendtian, judgment-driven model of political objectivity,

\footnotetext{
Urszula Lisowska

The Department of Social and Political Philosophy

The Institute of Philosophy

The University of Wrocław

ul. Koszarowa 3/20, 51-149 Wrocław

${ }^{1}$ Rawls (1993/1996).

${ }^{2}$ Larmore (1987/2001); Larmore (1996/2003).

${ }^{3}$ Given that the paper is concerned only with one variety of judgment - i.e. political judgment - for simplicity's sake, I use the generic term "judgment". The question of the relationship between this specific form of judgment and judgment in general is not addressed here. See: footnote 75 .
} 
as presented by Linda M.G. Zerilli. ${ }^{4}$ At the same time, the reference to the Arendtian perspective offers several constructive suggestions, whose possible application to PL is sketched in the concluding part of the paper.

This juxtaposition may not seem the most obvious one. Indeed, the politico-liberal model of political objectivity has been criticised both internally ${ }^{5}$ and, recently, within the analytical tradition ${ }^{6}$ that would more readily be linked to PL. Yet, it is not argued that the Arendtian approach offers the only critical perspective on PL, let alone that the two models exhaust possible approaches to political objectivity. ${ }^{7}$ Instead, the paper proceeds from the assumption that the two are - at the same time - different and similar enough to render the proposed juxtaposition productive. ${ }^{8}$

\section{PL - outlining the concept}

Larmore and Rawls developed the idea of PL more or less simultaneously. Not to undermine the contribution of the former, in what follows I will focus on Rawls, whose turn towards PL was motivated by the attempt to reformulate his theory of justice ("justice as fairness") and as such constitutes a direct political application of the approach (whereas Larmore focuses more on the general idea of PL defined in the context of modern moral philosophy). I would like to suggest that the search for such modifications - and the resultant specificity of PL - can be explained by two sets of circumstances.

One of these is the immediate polemical setting in which PL emerged, as in 1980s liberal political philosophy came under assault from the so-called communitarians. Albeit problematic, the label of "a communitarian(ism)" captures one thing right - namely, these critics accused liberalism of underestimating the twofold value of community: as an inherent good and as the constituent of rationality. When Rawls says that the task of PL is to "apply the principles of toleration to philosophy itself," he clearly responds to the first challenge. He recognises that, by presenting liberal values as obtaining in all areas of human life (i.e. as constituting "a comprehensive doctrine"), liberalism disrespects the worldviews oriented by other commitments, such as communal belonging or adherence to authority. To avoid this paradoxically illiberal consequence, PL acknowledges the "fact of reasonable pluralism" (Rawls) ${ }^{10}$

\footnotetext{
${ }^{4}$ Zerilli's interpretation is but a particle of the extensive research on Arendt's account of judgment (see Beiner, Nedelsky [2001] for a selection of approaches). I have chosen Zerilli's reading because she applies it directly to the criticism of PL.

${ }^{5}$ See, e.g. Wenar (1995); see also Ferrara's revision of PL mentioned below.

${ }^{6}$ See, e.g., Enoch (2015) and Wietmarschen (2018). I would like to thank one of the Reviewers for introducing me to these readings.

7 See the reference to Chantal Mouffe below.

${ }^{8}$ As Linda M.G. Zerilli observed: "for as many passages as one could cite that [reveal the weaknesses of Rawls's approach] (...) Rawls's defenders (...) will cite others" (Zerilli [2016]: 159). In the spirit of this observation, this paper stems from the assumption that it may be productive to venture beyond not only the internal confines of PL but also beyond its direct milieu.

${ }^{9}$ Rawls (1993/1996): 154.

10 Ibidem: XVI-XVII.
} 
(or: "reasonable disagreement", Larmore $)^{11}$ - i.e. it recognises that internally non-liberal doctrines may still be parties to the normative consensus in a liberal polity (that is: be "reasonable").

This, in turn, calls for the revision of the status of liberal principles, which now have to be introduced in a manner acceptable to the holders of all reasonable doctrines, liberal and non-liberal alike. To explain how this is possible, Rawls introduces three restrictions. Firstly, PL has a limited subject, concerned as it is with "constitutional essentials and matters of basic justice." ${ }^{12}$ In other words, PL presents liberal values as valid in the political sphere, without addressing their relevance to other areas of human life. ${ }^{13}$ Therefore and secondly, liberal values are "presented as a freestanding view" - i.e.: without relying on any specific reasonable comprehensive doctrine. ${ }^{14}$ At this point, one naturally needs to ask what other basis liberal values could possibly have. Rawls's third and final restriction addresses this challenge, while also allowing for the other dimension of the value of community emphasised by communitarians. Namely, accepting the fact that the standards of rationality are always the products of a communal tradition of inquiries, PL acknowledges that liberalism is itself a tradition. For Rawls this means that, rather than being justified from an ahistorical "Archimedean point", liberal principles are "expressed in terms of certain ideas seen as implicit in the public political culture of a democratic society." 15 In other words, they reflect a specific political experience - that of "the political institutions of a constitutional regime and the public traditions of their interpretation."16

Treating liberal tenets as the products of a political tradition, PL defines its primary question as that of "how [emphasis mine] it is possible that there may exist over time a stable and just society of free and equal citizens profoundly divided by reasonable (...) doctrines" ${ }^{17}$ Importantly, then, the acknowledgement of liberalism's rootedness in liberal democracy allows Rawls to implicitly assume that the latter is possible. This, in turn, obliquely points to the other set of circumstances that define PL, namely - the scepticism about the viability of liberal democracy. Rawls mentions this point only very briefly, suggesting that whether or not liberal democracy is perceived as a feasible option is not so much a matter of argumentation as of a foundational decision, which "affects our background thoughts and attitudes about the world as a whole."18 Thus, if PL addresses the question of whether liberal democracy is possible at all, it does so only indirectly, by explaining how this can be so. In what follows, I challenge this very approach and show how it is linked to the underappreciation of judgment.

\footnotetext{
${ }_{11}$ Larmore (1996/2003): 152-174.

${ }^{12}$ I.e. basic political rights and "the basic structure of society" (the main social and economic institutions as the agents of distributive justice, Rawls [1997]: 767; Rawls [1993/1996]: 11-12).

13 Rawls (1993/1996): 11-12.

${ }^{14}$ Ibidem: 12-13.

15 Ibidem: 13.

16 Ibidem: 13-14.

17 Ibidem: XVIII.

18 Ibidem: LIX.
} 


\section{PL as an account of political objectivity}

Inasmuch as PL purports to provide a description of a particular political experience and be concerned only with political phenomena, it essentially involves the question of what constitutes political objects and their proper realm of objectivity. This is the first and basic sense in which PL is interested in political objectivity. Given that its aim is to defend a common standard of reasoning in the conditions of pluralism, three additional senses could be added. Firstly, the commitment to "freestanding" justification means that PL does not "decide in view of the whole truth" 19 (as citizens may hold different comprehensive truths and their criteria) but seeks a different benchmark of objectivity. Secondly, this implies that the status of facts within PL has to be addressed - if political objectivity is in any sense different from "unspecified" objectivity, the relevance (or the lack thereof) of facts as basic units of external reality needs to be explained. Finally, as Martha Nussbaum observes in her interpretation of the approach, PL's account of political objectivity should itself be justified politically. That is to say - we need "freestanding" reasons to support a model of objectivity that could claim validity in the conditions of pluralism. ${ }^{20}$

\section{Political constructivism}

The recognition of the second of the above points - i.e. the unobvious relationship between political objectivity and facts - is reflected by Rawls's decision to describe his conception as "political constructivism". In what follows, I analyse both elements of this approach to conclude by addressing the problem of facts once again.

\section{Constructivism}

As "constructivism", Rawls's approach involves two important assumptions. Firstly, it is based on practical, rather than theoretical reason, that is - it "is concerned with the production of objects according to a conception of these objects", rather than "with the knowledge of given objects." ${ }^{21}$ In other words, political objectivity does not deal with unmediated facts - anything that enters its scope is somehow processed by human understanding. The "somehow" is specified by "a certain procedure of construction (structure)." 22 Therefore and secondly, political objects are seen as the outcomes of this designated procedure. For Rawls, the process is defined by the search for the reflective equilibrium between considered judgments and universal principles, undertaken in the hypothetical situation of: a) freedom and equality and b) the ignorance of morally irrelevant factors. ${ }^{23}$

\footnotetext{
${ }^{19}$ Ibidem: 219.

${ }^{20}$ Nussbaum (2001): 887, 890.

${ }^{21}$ Rawls (1993/1996): 93.

22 Ibidem: 90.

${ }^{23}$ Reflective equilibrium is part of Rawls's contractualism and was already defined in his Theory of Justice. The two points mentioned above correspond to the concepts of "original position" and "the veil of ignorance", respectively (Rawls [1971/1999]: 15-19).
} 
This description itself conveys two basic ideas. Firstly, political objectivity is organised by the schematic models of society and its citizens that themselves are not construed but "simply laid out." ${ }^{4}$ That is to say, Rawls assumes that society structured by the principles of freedom and equality of citizens, who accept specific limitations on public reasoning, is possible (these are the conceptions according to which political objects are produced). Secondly, the procedure involves the appeal to judgment - or rather: judgments. Objectivity is generated through the equilibrium between universal principles (e.g. the principle of treating each person respectfully) and considered judgments, i.e. "provisional fixed points" concerning specific questions (e.g. the conviction that household duties should not prevent women from pursuing a career) - to speak objectively is to strike a balance between the two (e.g. by saying that respect for women as persons requires adequate maternity leave schemes) ${ }^{25}$ Thus, it is remarkable that Rawls's procedure of construing political objectivity does employ judgment, but only in one capacity - that of opinions, the products, rather than the process, of judging (indeed, Rawls uses the terms "judgments" and "convictions" interchangeably).

\section{"Politicalness"}

As "political", the constructivism that Rawls offers has a distinct aim, namely - that of providing "a public basis of justification on questions of political justice given the fact of reasonable pluralism [emphasis mine]." 26 That is to say, Rawls's political constructivism is concerned with "political" objects conceptualised in terms of the specific sense of "politicalness" - the one related to the political experience whose possibility Rawls wants to explain rather than demonstrating it.

I suggest that a useful way to outline the details of this approach is to present two fundamentally relevant concepts - "the reasonable" and "public reason" - focusing in particular on how judgment features in these categories. ${ }^{27}$ Although the former appears in such terms as "reasonable pluralism" and "reasonable comprehensive doctrines", it seems that these phenomena are secondary to the reasonableness of persons. ${ }^{28}$ In this capacity, the category further qualifies the ideas of society and citizens underlying Rawls's procedure of construction, ${ }^{29}$ consisting as it does of two basic aspects. Firstly, the reasonable is complementary to the model of society structured by

${ }^{24}$ Rawls (1993/1996): 103.

25 Rawls (1971/1999): 17-18.

${ }^{26}$ Rawls (1993/1996): 100.

${ }^{27}$ In what follows, I will also refer to the six criteria that Rawls names as necessary for any account of objectivity: 1) establishing "a public framework of thought" in which the concept of judgment can be applied and conclusions reached based on evidence and reasons; 2) defining the standards of a correct judgment; 3) specifying an order of reasons and assigning them to agents; 4) distinguishing the objective point of view; 5) providing an account of agreement in judgment, and 6) explaining disagreement in judgment (ibidem: 110-112, 212).

${ }^{28}$ Compare Rawls's assumption that "reasonable persons affirm only reasonable comprehensive doctrines" (ibidem: 59).

${ }^{29}$ The other feature included in Rawls's political conception of the person is rationality, i.e. the ability to define and pursue one's idea of the good (ibidem: 48-54). 
the values of freedom and equality in that it entails the readiness to propose and abide by fair (i.e. acceptable to fellow citizens as free and equal) principles of cooperation (provided that others do so as well). ${ }^{30}$ This means that the reasonable opens up the "public framework of thought sufficient for the concept of judgment to apply," thereby grounding political objectivity. That is to say: political objects can emerge only on the condition that citizens are ready to go beyond their subjectivity and formulate publicly testable judgments, rather than merely expressing their idiosyncratic preferences. ${ }^{31}$ Thus, the reasonable - rather than truth - provides the standard of objectivity and the correctness of judgment. ${ }^{32}$ The second aspect of the reasonable is the willingness to recognise "the burdens of judgment" - i.e. the factors which, inasmuch as they impede the process of judging, result in the imperfections of our judgments, thus explaining the inevitability of reasonable disagreement. As such, the burdens of judgment function as the limiting notion of political objectivity, curbing its ambitions to the modest confines of what we do have the chance to share, given the inescapable pluralism. ${ }^{33}$

The nature and content of these confines is conceptualised in terms of "public reason," 34 i.e. "the reason of equal citizens" that applies to liberal political values within the confines of the "»constitutional essentials « and questions of basic justice." 35 To simplify this complex category, public reason introduces the standard of judging correctly and a correct judgment by defining the order of reasons, the latter amounting to the imperative (the so-called "duty of civility"36) to give priority to the political values of public reason ${ }^{37}$ when addressing the matters within its proper scope (i.e. "»constitutional essentials « and questions of basic justice"). As such, public reason defines the politically objective point of view - to adopt an objective perspective in the political sense is to address the narrow spectrum of political objects in terms of public ideas, while avoiding potentially divisive non-public reasons. ${ }^{38}$

\footnotetext{
${ }^{30}$ Ibidem: 49-50.

${ }^{31}$ Ibidem: 53-54.

32 Ibidem: 111.

33 Ibidem: 54-58.

${ }^{34}$ It is worth emphasising that the reasonable seems to have a double function in PL. On the one hand, inasmuch as it constitutes the foundation of political objectivity, it provides the threshold that any judgment has to pass to be considered a valid political stance. On the other hand, the reasonable features among the ideas "implicit in the public political culture of a democratic society" - the idea of the person (see: footnote 29) and the idea of society as a fair system of cooperation (ibidem: 49-50) - that Rawls uses to articulate his theory of justice. Thus, while the reasonable describes an attitude required of citizens if they want to speak objectively in the political sense, it is also linked to specific content (further defined by a detailed account of how a political community should be organised). To put it shortly, then - to be reasonable is to speak in a certain manner about certain things. The connection between the reasonable and public reason stems precisely from this specificity of the former. 35 Ibidem: 213-214.

${ }^{36}$ Ibidem: 217.

${ }^{37}$ When defining the content of public reason, Rawls names two sets of values: the political values of liberal justice (such as equal political civil liberty, equal opportunity etc.) and the meta-values of public reason, which provide the guidelines of the inquiries about the first-order values (in this sense, public reason is self-affirmative; ibidem: 224).

${ }^{38}$ In some places, Rawls describes this strategy as "the method of avoidance" (Rawls [1985]: 231, 240, Rawls [1987/1999]: 434-437).
} 
Yet, it can be observed that this definition of objectivity is circular - the duty to give priority to public reason obtains in the area defined by public reason itself (which, additionally, consists partly in affirming its own precedence ${ }^{39}$ ). In other words, the concept of public reason seems to describe the functioning of an existing realm of objectivity (for example the one defined by Rawls's theory of justice), rather than explaining its very emergence. As such, it undermines the criterion of political objectivity specified by Nussbaum - for it could be asked: do we have any freestanding reasons for accepting the content of public reason or are the former circularly defined by the latter?

To respond to this difficulty, Rawls introduces two additional assumptions. Firstly, he recognises that there are many "forms of permissible public reason". While he acknowledges that some of them tend to "dominate over time", he also emphasises that "new variations [of public reason] can be proposed." ${ }^{40}$ I would like to suggest that both the "domination" and "the proposition" should be conceptualised in terms of judgment as a faculty. This is because, when explaining how public reason can evolve, Rawls introduces the concept of "a proviso". "Proviso" - the other modification of public reason - describes the possibility of appealing to non-public reasons while discussing public matters, provided that the former will be later spelt out in terms of public reason. ${ }^{41}$ This reservation results in "an inclusive" view of the latter ${ }^{42}-$ its content is to be regarded "conceptually, not historically" 43 and citizens are encouraged to aim at "understanding what earlier principles require under changed circumstances." ${ }^{44} \mathrm{It}$ would seem that the process of "understanding" should involve the ability to judge how our prior considered judgments are to be honoured in new contexts (I develop this suggestion below, when I introduce the Arendtian perspective). As a result, new variations of public reason could be "proposed" and later become entrenched as the dominant ones.

\section{Political constructivism and facts}

Thus, the description of political constructivism as PL's account of political objectivity suggests that it is crucial for this approach to offer a conception of judgment as a faculty - otherwise, it risks circularity. Yet, the question remains: does Rawls's (or, more generally, PL's) ${ }^{45}$ perspective in fact contain the resources necessary for such a theoretical development?

\footnotetext{
${ }^{39}$ See footnote 37.

${ }^{40}$ Rawls (1997): 775.

${ }^{41}$ Ibidem: 776, 783-784.

${ }^{42}$ Rawls (1993/1996): 247-248.

${ }^{43}$ Ibidem: 250.

44 Ibidem: XXIX.

${ }^{45}$ It is worth noticing that Larmore calls for the revival of judgment as a moral faculty (Larmore [1987/2003]: 1-21). Yet, he insists that it should not play the same role in politics, which instead ought to be arranged in a more predictable (bureaucratic, as he says) manner (ibidem: 40-42). At the same time, he links this restriction to the "displacement of politics" from the status of the central category of the communal life (ibidem: 41). This seems to imply that if politics did play a significant role in modern democracies, it would have to rely on the faculty of judgment. Incidentally, Larmore's observation suggests that, despite its name, PL does not leave much scope for politics. This, in turn, corroborates the critical arguments - presented below - that accuse PL of not being political enough.
} 
To address this issue, let me return to the problem that opened the review of political constructivism, i.e. the status of facts in the framework of this approach. In the conclusion of his discussion of political objectivity, Rawls emphasises that constructivism does not claim that facts are simply "conjured". Instead, he compares the role of facts in his theory to that of the conceptions of person and society, which suggests that facts are also "laid out" ${ }^{46} \mathrm{He}$ specifies this general remark by distinguishing two kinds of relevant facts. The first category contains aspects of reality that are "cited in giving reasons why an action or institution (...) is just or unjust." ${ }^{47}$ With respect to these facts, the constructivist procedure functions as a network for selecting those that are politically significant (thus, depending on the underlying assumptions, the relevant information about slavery may be the race of an enslaved person or the fact that she is treated as the master's property)..$^{48}$ The facts from the second category belong to "the content of justice" and "are given by the nature of the constructivist procedure." ${ }^{49}$ As it turns out, what Rawls means here are considered judgments, treated as "fixed points" and "basic facts" to be processed by the constructivist procedure..$^{50}$

Thus, Rawls holds on to the idea of judgments as established opinions - hard data to be organised, rather than produced. Moreover, as elements of the procedure, considered judgments influence the selection of the other category of facts. Thus, inasmuch as judgment is active here as a faculty, it only offers guidance as to how to interpret external facts based on the opinions that we already possess. As a result, PL's model of political objectivity explains how political objects are arranged into a coherent structure, but does not show how they emerge as political. ${ }^{51}$ In the end, then, the difficulty related to public reason is not overcome.

\section{Summary}

Rawls's account of political objectivity is thus compatible with his general strategy of demonstrating how a given type of society (i.e.: a democratic-liberal one) is possible, based on the assumption that it is indeed so. In fact, Rawls admits that it is the actual experience of effective communication that "normally suffices for objectivity." ${ }^{2}$ The underlying model of construing objectivity seems to be the movement from pluralism towards agreement - in the situation of what Rawls calls "overlapping consensus", citizens will ideally be able to cite diverse premises (provided by their comprehensive doctrines) to support the common set of conclusions (the content of public reason). ${ }^{53}$

\footnotetext{
${ }^{46}$ Rawls (1993/1996): 121.

47 Ibidem.

${ }^{48}$ Ibidem: 122.

${ }^{49}$ Ibidem: 121.

50 Ibidem: 124.

${ }^{51}$ Nussbaum (2001).

${ }^{52}$ Rawls (1993/1996): 120. See also Larmore's idea of the contextualist model of justification, according to which "not belief itself, but rather change of belief, forms the proper object of justification" (Larmore [1996/2003]: 60).

${ }^{53}$ Rawls (1993/1996): 12-13, 133-172.
} 
And yet, the preliminary condition of participating in the procedure is reasonableness - that is: the readiness to accept the models of society and its citizens underlying the construction of objectivity and further specified by the "dominating" model of public reason. In fact, then, Rawls starts from an agreement - a common core of political objectivity - to later explain how it can persists in the conditions of pluralism, while not addressing the question of how it could emerge in the first place.

\section{Critical arguments}

I have not only shown that PL's model of political objectivity is related to the underestimation of judgment as a faculty, but also suggested that this failure is critical to the entire approach. I would now like to strengthen this claim and argue that the underappreciation of judgment is symptomatic of a fundamental flaw of PL and therefore could be seen as a sign of a systematic difficulty. I will use Linda Zerilli's critical observations as a starting point for a more general diagnosis.

The core of Zerilli's argument is that - by underestimating the faculty of judgment - PL fails to take into account the dynamism of political objectivity. Addressing "the inclusive" account of public reason, Zerilli says that the modifications introduced by Rawls serve "as the mere extension of the inherent logic of rights" 54 already included in public reason. Indeed, if proviso allows for the use of non-public reasons on the condition that they will be later spelt out in terms of public reason, its function is to find the new applications, rather than the new senses, of the latter. ${ }^{55}$ Semiotically speaking, Zerilli argues, this strategy misconstrues the relationship between meaning and use - political liberals give priority to judgments as opinions over judgment as a faculty because they assume that the meaning of a sentence is prior to and determines its use. Zerilli, in turn, follows Wittgenstein in reverting this order; as a result, she claims that each use of a judgment-opinion co-constitutes its meaning and opens room for its new senses. ${ }^{56}$ Thus, any act of voicing a judgment is also an act of judging - the decision to express a judgment in a new context is itself an activity of judging and potentially adds a new twist to the content of the judgment. ${ }^{57}$

With respect to political objectivity, Zerilli's approach entails that there is no closed set of objects that are regarded as political and therefore could become the topic of political judgment. Therefore, what makes judgment political is not its object

\footnotetext{
${ }^{54}$ Zerilli (2016): 151.

${ }^{55}$ Zerilli diagnoses a similar - though more extensive - flaw in Nussbaum's appropriation of PL. For whereas Rawls and Larmore restricted the validity of PL to Western democracies, Nussbaum argues that the model is applicable globally - both internally, within non-Western countries, and internationally, as a template for conceptualising global justice (Nussbaum [2014]). This, Zerilli argues, helps Nussbaum develop a new version of universalism, which substitutes the old strategy of "exporting" local values with their "attribution" to different contexts (Zerilli [2016]: 166-173). That is to say, Western and non-Western cultures are scanned for their similarities against the background of a specific - in fact: Western - account of what Nussbaum calls "the best ideas". As a result, we can "think about Western and non-Western cultures as always already sharing their best ideas" (ibidem: 170).

${ }^{56}$ Zerilli (2016): 145-152.

${ }^{57}$ Ibidem: 153-157.
} 
but its "mode [italics in the original]" - the specificity of the act of judging itself. ${ }^{58}$ I will elaborate on the underlying Arendtian model of political objectivity in the next section. For now I would like to highlight that Zerilli understands the feature of "politicalness" processually - judgments are political inasmuch as they contribute to construing political objectivity, rather than merely addressing the constructs that already occupy the scope of the latter. The circularity of PL's account of public reason links judgment to the latter function. As a result, to the extent that judgment features in PL as a faculty, it is treated as a means of adjudicating or justifying claims within the recognised field of objectivity, rather than as an onto-political force that participates in its creation. ${ }^{59}$ Consequently, PL omits the meta-political dimension of political objectivity - the level of politically justifying political objectivity that Nussbaum, speaking as a representative of PL, recognised had to be included.

The reason why I believe the underappreciation of judgment is symptomatic of a systemic flaw of PL is that the gist of Zerilli's criticism could also be formulated in different idioms, such that do not appeal to the category of judgment. Firstly, it is worth observing that, of the two analytical critics of PL mentioned at the beginning, ${ }^{60}$ Enoch concludes his analysis by arguing that the concept of public reason is not an epistemological one at all. Instead, he argues, public reason articulates "moral and political reasons" which only later provide the basis for specific epistemic standards. ${ }^{61}$ Thus, Enoch's diagnosis is compatible with Zerilli's de-prioritisation of justification - he likewise suggests that the requirements of public reason cannot be justified because they themselves define the content and procedures of adjudication. ${ }^{62}$ However, as such PL cannot but rely on at least one comprehensive value (most probably: autonomy), thereby subverting itself. ${ }^{63}$ Secondly, what I have called "the meta-political dimension of political objectivity" could be expressed in terms of Chantal Mouffe's category of "the political" as opposed to "politics", the two being linked to the ontological and the ontic levels respectively.$^{64}$ Indeed, Mouffe described Rawls's PL as "political philosophy without politics", meaning that without the acknowledgment of the dynamic, processual (and, on Mouffe's interpretation, antagonistic) ontological dimension of the political no robust politics - as the set of established practices that channel the former - is possible. Inasmuch as it focuses on how liberal democracy works and simply assumes that it does, PL obliterates the fact that liberal-democratic politics is a result of a contingent reconfiguration ("the democratic revolution") at the level of the political. If, in turn, liberal-democratic values that constitute the basic coordinates of political objectivity are treated as given, it is difficult to explain how their

\footnotetext{
58 Ibidem: 6-10.

59 Ibidem: 266-269.

${ }^{60}$ See footnote 6.

${ }^{61}$ Enoch (2015): 42.

${ }^{62}$ In contrast to Enoch, Wietmarschen seems to confine his arguments to the dimension of justification. He accuses PL of what he calls "justificatory incoherence" (JI) showing that reasonable citizens cannot hold a comprehensive doctrine and at the same time accept its disputability (Wietmarschen [2018]: 497-503).

${ }^{63}$ Enoch (2015): 43.

${ }^{64}$ Mouffe (2005): 8-9.
} 
specific interpretations emerge and come to dominate (in Mouffe's idiom: impose their hegemony) and how they could be challenged and revised (in Mouffe's idiom: how counter-hegemonic project could be formulated). Thus, like Zerilli, Mouffe criticises PL for prioritising political constructs over the process of their construction and likewise links this flaw to the misunderstanding of demands of "politicalness". ${ }^{65}$

The points raised by Zerilli, Enoch and Mouffe reveal a systemic difficulty in PL because they suggest that its focus on the "how" of liberal democracy undermines the assumption that this political regime is possible. That is to say: not only does the former research question fail to indirectly address the latter, but it can also lead to illiberal and undemocratic consequences. PL seems to strive for political objectivity in spite of, rather than through, pluralism. ${ }^{66}$ From this point of view, as Zerilli observed, "pluralism, though clearly an achievement of liberal democracy, is also its greatest threat." ${ }^{67}$ To achieve objectivity, differences should be "contained", ${ }^{68}$ rather than being effectively included in construing objectivity.

\section{An alternative account of political objectivity}

Yet, despite its far reaching consequences, Zerilli's criticism of PL has an air of a complaint about an unfulfilled promise, rather than of a downright rejection. Indeed, she suggests that the reasonable - as the injunction to speak publicly and to recognise the limitations of one's own perspective in the process ("the burdens of judgment") - should, and, therefore, presumably, could, be "unshackled from the constraints of public reason." 69 The route to such liberation, Zerilli argues, leads through an alternative - Arendt-inspired - account of political objectivity, which crucially involves judgment as a faculty. ${ }^{70}$ Interestingly, a similar suggestion has been made within PL: in his sympathetic rereading of the approach, Alessandro Ferrara argues that the reasonable should be understood as the ability to revise the boundaries of public reason through the exercise of judgment, interpreted Arendtian-wise. ${ }^{71}$ This unanimity between an external critic of PL and its internal reformer is striking. Therefore, in this final part of the paper I would like to sketch the Arendtian model of objectivity (as Zerilli articulates it) to later conclude by offering an agenda for the future research on its application to PL.

The common point between PL and the Arendtian perspective is that they both start from acknowledging that there is no a priori concept of the good from

\footnotetext{
${ }^{65}$ Mouffe (1993): 41-59.

${ }^{66}$ Wietmarschen's analysis (Wietmarschen [2018]), limited though it is to the issue of adjudication, would also support this conclusion. For his charge of JI in fact suggests that PL cannot fulfil its promise of accommodating pluralism. To overcome JI, citizens would have to abandon either their profound and potentially conflict-engendering differences or the willingness to seek common ground.

67 Zerilli (2016): 267.

${ }^{68}$ Rawls uses this ambiguous verb when he speaks about PL's recommended treatment of unreasonable comprehensive doctrines. Rawls (1993/1996): XVII.

${ }^{69}$ Zerilli (2016): 146. See footnote 34.

${ }^{70}$ Ibidem.

${ }^{71}$ Ferrara (2008): 62-79.
} 
which politics should proceed. ${ }^{72}$ But, Zerilli argues, whereas PL ends up petrifying an a posteriori ideal of a society that sets the standard of objectivity for judgment, the Arendtain account derives objectivity from the process of judging itself. In terms of Kant's theory of judgment - which provided the template for the Arendtian approach $^{73}$ - PL employs judgment in a determinative capacity: judging consists in applying pregiven concepts to particular cases. In contrast to PL, the Arendtian account appeals to reflective judgment: the ability to judge without a predetermined concept so as to capture the universal dimension of the particular. ${ }^{74}$ The link between judgment thus understood and political objectivity comes out at two junctures. Firstly, the Arendtian political objectivity is a "worldly" one - it obtains in "the world" understood as a network of human-made meanings, rather than in an unmediated, natural reality. ${ }^{75}$ Things are objective insofar as they "can be seen by many in a variety of aspects without changing their identity." ${ }^{76}$ Importantly, then, objectivity is not achieved in spite of pluralism, but rather through it. ${ }^{77}$ Secondly, the manner of "seeing" that creates objectivity is conceptualised as sensus communis - understood Kantian-wise, as the basis of reflective judgment that "fits" the private senses "into a common world shared by others." 78

These two assumptions enable Zerilli to present judgment as a "world-building" capacity, which itself involves two moments. On the one hand, Zerilli argues that it is through the practice of judging politically that judgments-opinions can gain political objectivity. For it is when a citizen applies the standard of "worldliness" to her judgment and thinks "representatively" - "considering an issue from different viewpoints," while retaining her "own identity"79 - that her opinion becomes objective and the universality of its particularity can be communicated. Thus, no judgment can be excluded as unobjective prior to the actual operation of judging. ${ }^{80}$ On the other hand, it is the voicing of judgments (i.e. the practice of judging) that construes political objectivity. Political objects emerge through the intersection of judgments, each of which offers a specific way of seeing an object. Judgment thus understood is "unshackled" from the constraints of predetermined concepts - rather than operating within the prior boundaries of objectivity, it challenges and revises those frontiers. ${ }^{81}$

\footnotetext{
${ }^{72}$ Zerilli (2005): 129.

${ }^{73}$ See: Arendt (1992).

${ }^{74}$ Kant (1790/1987): 18-120. Compare: Zerilli (2005): 127-131

${ }^{75}$ Interestingly, then, for Arendt objectivity seems to be a political concept (rather than there being a specifically political type of objectivity). And if that is the case, the same goes for judgment, inasmuch as, as I argue below, it is the objectivity-creating force (Zerilli [2016]: 6-9). However, I do not address this far reaching claim here. I am interested in what the Arendtian approach can tell us about political objectivity, quite apart from its implications for the understanding of objectivity as such(see footnote 3).

${ }^{76}$ Arendt (1958/1998): 57.

77 Zerilli (2016): 28-40.

78 Arendt (1971/1978, 1977): 50. Compare also Sjöholm (2015): 81-85 on the additional senses of "the common sense" in Arendt.

${ }^{79}$ Arendt (1961/2006): 237.

80 Zerilli (2016): 31-33, 121-135.

${ }^{81}$ Ibidem: 153-162. Compare also: Zerilli (2005): 139-163.
} 


\section{Future research}

What could PL learn from the Arendtian approach, then ${ }^{82}$ Firstly, the conceptualisation of judgment as a reflective faculty could serve to emphasise the active aspect of the reasonable, thereby "unshackling" it from the content specified by public reason. As a result and secondly, the dynamic, meta-political dimension of political objectivity could be captured with the reasonable functioning as a mode of construing, rather than a mere means of systematising, political objects. At the same time and thirdly, the Arendtian influence would not render PL's model of objectivity purely procedural. After all, on Zerilli's reading, the Arendtian approach serves to vindicate the value of individual perspectives. Thus, the transformation would involve not so much the eradication of any content from political objectivity, as its diversification and the relaxation of the restrictions of public reason..$^{83}$

To put more flesh on this outline, I would like to conclude by mapping the programme for future research. My suggestion is that the development of a robust politico-liberal model of judgment - with the help of the Arendtian insights - would require moving beyond Rawls's canonical version of the paradigm and towards its interpretation offered by Nussbaum. This is for three reasons. Firstly, in her early ethical writings, Nussbaum looked to Aristotle to develop a model of public reasoning based on "perception".${ }^{84}$ Rather than deducing specific decisions from universal principles, perception treats the latter as "rules of thumb" that provide some guidance, but might as well be redefined in the process of decision making. As such, perception resembles the faculty of reflective judgment, as opposed to Rawls's belief-like "considered judgments" ${ }^{85}$ When included as part of the politico-liberal virtue of reasonableness, perception could thus make it more active.

However, it could be objected that, given its Aristotelian underpinnings, the model of perception is incompatible with PL, dedicated as the latter is to the "freestanding" justification of political values. Indeed, it has been argued that Nuss-

\footnotetext{
${ }^{82}$ It is worth noticing that the merger with PL could be beneficial to the Arendtian perspective as well. For the short description of the latter raises two important questions. Firstly: whose (which) "viewpoints" are to be taken into account in the process of representative thinking? And secondly: could the re-evaluation of individual perspectives nonetheless be combined with an account of a collective political identity? In other words, whereas PL (with its appeal to a specific public political culture further articulated in terms of public reason) may seem too restrictive, the Arendtian approach could be criticised as not robust enough. Therefore, the two models could turn out to be complementary, with their respective weaknesses becoming strengths when cross-applied. Although this paper focuses on how the Arendtian account could contribute to PL, future research on the actual (i.e. mutual) exchange between the two does seem possible.

${ }^{83}$ In Rawls's idiom, the relevant change would involve the reinterpretation of the status of burdens of judgment. As of now, they function as the negative limit of objectivity that necessitates the very search for a specifically political type of objectivity (presumably, then, if our judgments were not burdened, disagreements would disappear; compare: Zerilli [2016]: 157-159; see also Enoch [2015]: esp. 26-29, where he questions the possibility of justifying reasonable pluralism in terms of burdens of judgment). On the Arendtian account, burdens of judgments would instead be treated as idiosyncrasies that have to be transformed (in the process of representative thinking) rather than avoided.

${ }^{84}$ Nussbaum (1990/1992).

${ }^{85}$ See in particular ibidem: 3-53, 54-105, 168-194.
} 
baum did not succeed in liberating her philosophical project from the Aristotelian background and therefore is not justified in calling herself a political liberal. ${ }^{86}$ Yet, I have suggested that, even in its original Rawls's formulation, PL is "burdened" with a specific content. Therefore, Nussbaum's reliance on Aristotelianism in itself does not undermine her claim to PL. I have also argued that the point is not so much to abandon any content of political objectivity whatsoever, as to make it flexible and sensitive to individual perspectives. Nussbaum's project is attractive in this respect - and this is its second possible contribution to a politico-liberal model of judgment. To put it briefly, Nussbaum's PL is based on the idea of the "thorough intertwinement" of the good, tailored to the (Aristotelian) account of the human condition, and the right, expressed by the notion of dignity. ${ }^{87}$ The latter is, in turn, conceptualised in Kantian terms, as the imperative to treat each person as an end in herself. ${ }^{88}$ Thus, Nussbaum's political philosophy does rely on a specific content (an account of human flourishing), but the latter is open to revision in response to individual cases (particular persons as ends in themselves).

Together, perception and the Aristotelian-Kantian concept of dignity could provide a template for a revised politico-liberal model of objectivity, whereby perception-judgment would function as the method of construing political objects understood as the basic conditions of a life compatible with human dignity. ${ }^{89} \mathrm{How}-$ ever, as the third and final point, it is worth adding that Nussbaum does not treat dignity as an exclusively human quality. Indeed, she urges the recognition of the plural forms of dignity, characteristic of different beings. This postulate has, in turn, inspired Nussbaum's interpreter, Jeremy Bendik-Keymer, to suggest that her "outlook" is in fact "biocentric" - the bearers of dignity are living beings in general and it is against this background that the value of human dignity can be grasped and its meaning construed. ${ }^{90}$ The reason why I find this interpretative direction relevant to political objectivity is that it helps address its meta-political dimension (i.e. the political justification of political objectivity). For if human dignity - as the matrix of political objectivity - is perceptively construed in relation to living dignity at large, it is possible to capture the moment when human life enters the political realm, when dzoe becomes bios - to use the ancient Greek terms. ${ }^{91}$ Thus, Nussbaum's biocentrism has the potential of tapping into the very foundations of politics, allowing us to ask when and in what forms human life emerges as a political category and the core of political objectivity.

This programme for the future research only sketches an outline of the nodal points that could be developed. The intention of this paper has been to make the first contribution to the politico-liberal model of judgment by arguing that: PL, as

\footnotetext{
${ }^{86}$ See, e.g., Barclay (2003), Biondo (2008), Alexander (2014).

87 Nussbaum (2006/2007): 161-162.

${ }^{88}$ Nussbaum (2000): 59-70.

${ }^{89}$ In Nussbaum's lexicon these basic conditions are expressed in terms of ten central human capabilities (ibidem: 70-86).

90 Bendik-Keymer (2014), Bendik-Keymer (2017).

${ }^{91}$ For the distinction between $d z o e$ and bios (and its role in Western political philosophy and metaphysics) see, e.g., Arendt (1958/1998): 96-97, Agamben (1998): 1-12.
} 
an account of political objectivity, already recognises the importance of judgment in some form; the concept is nonetheless underdeveloped and yet crucial to the entire approach; the Arendtian perspective offers a good vantage point for both criticising and refining PL; and the latter could be achieved by drawing on Martha Nussbaum's version of the paradigm. Following up on this last point would constitute the next step to formulating a politico-liberal conception of judgment.

\section{References}

Arendt H. (1961/2006), Truth and Politics, [in:] H. Arendt, Between Past and Future. Eight Exercises in Political Thought, Penguin, New York: 233-259.

Arendt H. (1971/1978, 1977), The Life of the Mind, A Harvest Book, Harcourt Inc., San Diego, New York, London.

Arendt H. (1992), Lectures on Kant's Political Philosophy, The University of Chicago Press, Chicago.

Barclay L. (2003), "What Kind of Liberal is Martha Nussbaum," Sats - Nordic Journal of Philosophy 4 (2): 6-23.

Beiner R., Nedelsky J. (eds.) (2001), Judgment, Imagination, and Politics. Themes from Kant to Arendt, Rowman \& Littlefield Publishers, Inc., Lanham.

Bendik-Keymer J. (2014), From Humans to All of Life: Nussbaum's Transformation of Dignity, [in:] Capabilities, Gender, Equality. Towards Fundamental Entitlements, F. Comim, M.C. Nussbaum (eds.), Cambridge University Press, Cambridge: 175-191.

Bendik-Keymer J. (2017), “The Reasonableness of Wonder," Journal of Human Development and Capabilities 18 (3): 337-355.

Biondo F. (2008), "Is Martha Nussbaum Really Political Liberal," Archives for Philosophy of Law and Social Philosophy 94 (3): 311-324.

Enoch D. (2015), "Political Philosophy and Epistemology: The Case of Public Reason," Oxford Studies in Political Philosophy 3.

Ferrara A.(2008), The Force of the Example. Explorations in the Paradigm of Judgment, Columbia University Press, New York, Chichester.

Kant I. (1790/1987), Critique of Judgment, trans. W.S. Pluhar, Hackett Publishing Company, Indianapolis/Cambridge.

Larmore Ch. (1987/2003), Patterns of Moral Complexity, Cambridge University Press.

Larmore Ch. (1996/2003), The Morals of Modernity, Cambridge University Press, Cambridge.

Mouffe Ch. (1993), The Return of the Political, Verso, London, New York.

Mouffe Ch. (2005), On the Political, Routledge, London and New York.

Nussbaum M.C. (1990/1992), Love's Knowledge. Essays on Philosophy and Literature, Oxford University Press, Oxford.

Nussbaum M.C. (2000), Women and Human Development. The Capabilities Approach, Cambridge University Press, New York.

Nussbaum M.C. (2001), "Political Objectivity," New Literary History 32(4): 883-906.

Nussbaum M.C. (2006/2007), Frontiers of Justice Disability, Nationality, Species Membership, The Belknap Press of Harvard University Press, Cambridge (MA), London (UK).

Nussbaum M.C. (2014), Introduction. Capabilities, Challenges, and the Omnipresence of Political liberalism, [in:] Capabilities, Gender, Equality. Towards Fundamental Entitlements, F F. Comim, M.C. Nussbaum (eds.), Cambridge University Press, Cambridge: 1-15. 
Rawls J. (1971/1999), A Theory of Justice. Revised Edition, The Belknap Press of Harvard University Press, Cambridge (MA).

Rawls J. (1985), "Justice as Fairness: Political not Metaphysical," Philosophy and Public Affairs 14 (3): 223-251.

Rawls J. (1987/1999), The Idea of an Overlapping Consensus, [in:] J. Rawls, Collected Papers, Harvard University Press, Cambridge (MA), London (UK): 421-448.

Rawls J. (1993/1996), Political Liberalism, Columbia University Press, New York.

Rawls J. (1997), “The Idea of Public Reason Revisited," The University of Chicago Law Review 64 (3): 765-807.

Sjöholm C. (2015), Doing Aesthetics with Arendt. How to See Things, Columbia University Press, New York.

Wenar L (1995), “Political Liberalism: an Internal Critique,” Ethics 106 (1): 32-62.

Wietmarschen H. v. (2018), "Reasonable Citizens an Epistemic Peers: A Skeptical Problem for Political Liberalism," Journal of Political Philosophy 26 (4): 486-507.

Zerilli L. M. G. (2005), Feminism and the Abyss of Freedom, The University of Chicago Press, Chicago and London.

Zerilli L. M. G. (2016), A Democratic Theory of Judgment, The University of Chicago Press, Chicago and London. 